\title{
PTH/PTHrP Receptor Is Temporally Regulated During Osteoblast Differentiation and Is Associated With Collagen Synthesis
}

\author{
Laurie K. McCauley, Amy J. Koh, Christopher A. Beecher, Yingqi Cui, Thomas J. Rosol, \\ and Renny T. Franceschi \\ The University of Michigan, School of Dentistry, Department of Periodontics/Prevention/Geriatrics \\ (L.K.M., A.J.K., C.A.B., Y.C., R.T.F.) and Biological Chemistry (R.T.F.), Ann Arbor, Michigan 48109-1078; \\ and The Ohio State University Department of Veterinary Biosciences (T.J.R.), Columbus, Ohio
}

\begin{abstract}
The temporal sequence of PTH/PTHrP receptor mRNA, binding, biologic activity, and its dependence on matrix synthesis was determined using MC3T3-E1 preosteoblast-like cells and primary rat calvarial cells in vitro. Osteoblastic cells were induced to differentiate and form mineralized nodules with the addition of ascorbic acid and $\beta$-glycerophosphate, and samples were collected from 0-26 days of culture. DNA levels as determined by fluorometric analysis increased 12- and 17-fold during the collection period for both MC3T3-E1 and primary calvarial cells respectively. Steady state mRNA levels for the PTH/PTHrP receptor as determined by northern blot analysis, were initially low for both cell types, peaked at day 4 and 5 for MC3T3-E1 and primary calvarial cells respectively, and declined thereafter. Competition binding curves were performed during differentiation using ${ }^{125}$ I-PTHrP. The numbers of receptors per $\mu \mathrm{g}$ DNA were greatest at days 3 and 5 for MC3T3-E1 and primary calvarial cells respectively. The biologic activity of the receptor was evaluated by stimulating the cells with $10 \mathrm{nM}$ PTHrP and determining CAMP levels via a binding protein assay. The PTHrP-stimulated cAMP levels increased 5-fold to peak values at day 5 for MC3T3-E1 cells and 6 -fold to peak values at day 4 for the primary calvarial cells. Ascorbic acid was required for maximal development of a PTH-dependent cAMP response since ascorbic acid-treated MC3T3-E1 cells had twice the PTHstimulated CAMP levels as non-treated cells. When the collagen synthesis inhibitor 3,4-dehydroproline was administered to MC3T3-E1 cultures prior to differentiation, there was a subsequent diminution of the PTH/PTHrP receptor mRNA gene expression and numbers of receptors per cell; however, if administered after the initiation of matrix synthesis there was no reduction in PTH/PTHrP receptor mRNA. These findings indicate that the PTH/PTHrP receptor is associated temporally at the level of mRNA, protein, and biologic activity, with a differentiating, matrix-producing osteoblastic cell in vitro. 1996 Wiley-Liss, Inc.
\end{abstract}

Key words: osteoblast, bone, parathyroid hormone, receptor, differentiation, collagen

Parathyroid hormone (PTH) is a major regulator of systemic calcium metabolism at least in part via its interaction with cell surface receptors on osteoblastic cells [Jüppner et al., 1991]. $\mathrm{PTH}-$ related protein (PTHrP) is an autocrine or paracrine factor that binds to the same receptor on osteoblastic cells. PTH and PTHrP have been found to have both anabolic and catabolic effects in bone; although the mechanisms of action of these two diverse effects are not known. Osteo-

Received September 15, 1995; accepted December 26, 1995. Address reprint requests to Laurie K. McCauley, The University of Michigan, School of Dentistry, Department of Periodontics/Prevention/Geriatrics, Ann Arbor, MI 481091078.

1996 Wiley-Liss, Inc. blasts progress through a well characterized pattern of proliferation and differentiation and are responsible for forming the mineralized matrix of bone [Lian and Stein, 1992]. Knowledge of the specific stages during differentiation in which the osteoblast is responsive to $\mathrm{PTH}$ and $\mathrm{PTHrP}$ is critical to determine the precise mechanisms of anabolic and catabolic effects of PTH and $\mathrm{PTHrP}$ in bone.

Numerous studies have characterized the osteoblast phenotype during cultivation of cells and production of a mineralized matrix in vitro [Malaval et al., 1994; Franceschi and Iyer, 1992; Tenenbaum and Heersche, 1982]. One of the characteristics often used to classify osteoblastic cells is the presence of $\mathrm{PTH} / \mathrm{PTHrP}$ receptors or 
biologic response to $\mathrm{PTH}$ in vitro [Wong, 1990]. Several studies suggest that the presence of the $\mathrm{PTH} / \mathrm{PTHrP}$ receptor is associated with a specific stage of differentiation; however, there are no reports correlating the expression of the $\mathrm{PTH} /$ PTHrP receptor at the mRNA, ligand binding, and biologic activity levels. An in vivo autoradiographic study reported that PTH binding was localized over cells described as immature stromal cells [Rouleau et al., 1988]. In contrast, $\mathrm{PTH} / \mathrm{PTH}$ P receptor $\mathrm{mRNA}$ levels were greatest in active osteoblasts lining trabecular bone as demonstrated by in situ hybridization [Lee et al., 1994]. In vitro, it has been suggested that the $\mathrm{PTH} / \mathrm{PTHrP}$ receptor is associated with a mature, cuboidal cell, and that it is expressed as osteoblastic cells differentiate [Yamamoto et al., 1988; Turksen and Aubin, 1991]; however, detailed analysis is lacking.

Expression of other osteoblast marker proteins such as alkaline phosphatase and osteocalcin requires growth of cells in ascorbic acidcontaining medium [Franceschi and Iyer, 1992]. We recently reported that the ascorbic acid requirement is related to the ability of this vitamin to stimulate collagen matrix formation since incorporation of proline analogues into procollagen that disrupt the triple-helical structure of this molecule prevented the induction of osteoblast marker protein genes [Franceschi and Iyer, 1992; Franceschi et al., 1994]. It is not known if expression of the $\mathrm{PTH} / \mathrm{PTHrP}$ receptor similarly requires collagen matrix synthesis.

The objectives of the present study were to determine the temporal sequence of expression and activity of the PTH/PTHrP receptor during osteoblastic differentiation in vitro and to resolve whether receptor expression requires the synthesis of a collagenous matrix. These studies provide insight into the character of cells which respond to $\mathrm{PTH}$ or PTHrP and may be important in designing treatment strategies for targeting anabolic actions of PTH in bone.

\section{MATERIALS AND METHODS Cell Culture}

MC3T3-E1 cells were obtained from Dr. M. Kumegawa (Meikai University, Sakado, Japan) and maintained as previously described [Franceschi and Iyer, 1992]. Briefly, stock cultures were grown in $\alpha$-modified Eagle's medium ( $\alpha$ MEM) (JRH Biosciences) and 10\% fetal bovine serum containing 100 units $/ \mathrm{ml}$ of penicillin and streptomycin. Cells were passaged every $4-5$ days and were not used beyond passage 15 . MC3T3-E1 cells were plated at initial densities of $10,000 / \mathrm{cm}^{2}$ except in studies that examined the requirement for ascorbic acid and collagen synthesis on receptor expression where cells were plated at an initial density of $50,000 / \mathrm{cm}^{2}$.

Primary rat calvarial cells were isolated according to published techniques [Pockwinse et al., 1992]. Briefly, calvaria of fetal rats of 21 days gestation were dissected, isolated from periosteum, and subjected to sequential digestions of 20,40 , and $90 \mathrm{~min}$ in collagenase $\mathrm{A}(2 \mathrm{mg} / \mathrm{ml}$, Boehringer-Mannheim, Indianapolis, IN) with 0.25\% trypsin (Gibco BRL, Grand Island, NY). Cells from the third digest were washed, counted, and plated in $\alpha$-MEM with $10 \%$ fetal bovine serum containing 100 units $/ \mathrm{ml}$ of penicillin and streptomycin, at a density of $20,000 / \mathrm{cm}^{2}$. Primary cultures were used without passage.

Cells were plated in either $35 \mathrm{~mm}$ (cAMP assays), $60 \mathrm{~mm}$ tissue culture dishes (RNA isolation), or 24-well plates (receptor binding assays) at an initial density of 10,000 or 20,000 cells/ $\mathrm{cm}^{2}$. After $24 \mathrm{~h}$ (MC3T3-E1 cells) or 4 days (primary calvarial cells), medium was changed to $\alpha$-MEM with $10 \%$ fetal bovine serum supplemented with $50 \mu \mathrm{g} / \mathrm{ml}$ of ascorbic acid (Sigma) and $10 \mathrm{mM} \beta$-glycerophosphate (Sigma) to induce osteoblastic differentiation and mineralization in vitro. The concentration of ascorbic acid used in these experiments optimally stimulates differentiation of MC3T3-E1 cells [Franceschi and Iyer, 1992] and saturates a recently described plasma membrane-associated ascorbate transporter [Franceschi et al., 1995].

\section{Northern Blot Analysis}

RNA was isolated and northern blot analysis performed as described [McCauley et al., 1994]. Briefly, total RNA was isolated from one $60 \mathrm{~mm}$ dish by the guanidinium isothiocyanate method [Chomczynski and Sacchi, 1987] and quantitated by spectrophotometry. Total RNA $(20 \mu \mathrm{g})$ was electrophoresed on $1.2 \%$ agarose-formaldehyde gels. The RNA was transferred to nylon membranes (Duralon U.V., Stratagene Inc. La Jolla, CA) and U.V. crosslinked. The nylon membranes were hybridized with a cDNA probe (R15B) encoding the rat PTH/PTHrP receptor [Abou-Samra et al., 1992]. After hybridization and washing, blots were exposed to Kodak XOMAT film at $-70^{\circ} \mathrm{C}$ for $24-72 \mathrm{~h}$. Blots were also stripped and reprobed with a cDNA probe 
for $18 \mathrm{~S}$ rRNA [Renkawitz and Gerbi, 1979], to control for RNA loading.

Autoradiographs were evaluated for relative signal density with NIH Image Software and data expressed as a ratio of signal density for $\mathrm{PTH} / \mathrm{PTHrP}$ receptor vs. $18 \mathrm{~S} \mathrm{rRNA}$.

\section{Receptor Binding Assays}

PTH/PTHrP receptor binding assays were performed as described [McCauley et al., 1992a]. Briefly, cells were plated in 24-well plates and binding assays performed at the indicated times after the introduction of ascorbic acid and $\beta$-glycerophosphate to culture media. Triplicate wells were incubated with $20,000 \mathrm{cpm}$ of high performance liquid chromotography-purified monoiodinated-125I-[Tyr $\left.{ }^{36}\right]$-hPTHrP (1-36) amide [McCauley et al., 1992b], in addition to varying concentrations of nonradioactive hPTHrP (134) amide (Bachem Inc., Torrance, CA). The cells were incubated for $2 \mathrm{~h}$ at $4^{\circ} \mathrm{C}$ with gentle shaking. The unbound peptides were washed twice from the cell monolayer with Hank's buffered salt solution (HBSS), the cells were lysed with $0.5 \mathrm{M} \mathrm{NaOH}$ for $30 \mathrm{~min}$, and the resultant suspension counted in a scintillation counter. Three wells from each plate were utilized to determine DNA levels as described using fluorimetric analysis [McCauley et al., 1995].

\section{Adenylate Cyclase Stimulation Assay}

The adenylate cyclase stimulation assay and cAMP binding assay were performed as previously described [McCauley et al., 1992b]. Briefly, for each time point, six $35 \mathrm{~mm}$ dishes of MC3T3-E1 or primary rat calvarial cells were evaluated. Three plates were stimulated with 10 nM hPTHrP (1-34) amide, hPTH (1-34) amide (Bachem Inc.), or vehicle control as indicated for $10 \mathrm{~min}$ at $37^{\circ} \mathrm{C}$ in calcium- and magnesium-free HBSS containing $0.1 \%$ bovine serum albumin (BSA) and $1 \mathrm{mM}$ isobutylmethylxanthine (IBMX). PTH and PTHrP bind to the PTH/ PTHrP receptor on osteoblastic cells with similar binding affinity and biologic activity [Jüppner et al., 1988]. The media was aspirated and $750 \mu \mathrm{l}$ ice-cold $5 \%$ perchloric acid was added to each well. The plates were incubated at $-20^{\circ} \mathrm{C}$ overnight to extract the cAMP. After thawing, the extract was transferred to tubes, the $\mathrm{pH}$ was adjusted to 7.5 with $4 \mathrm{~N} \mathrm{KOH}$, and the extract was centrifuged to remove the precipitate. The neutralized extract was then assayed for cAMP content using a cAMP binding protein assay.
Parallel wells were analyzed for DNA content by fluorimetric analysis as described above.

The cAMP binding protein assay was performed as follows. To each tube was added assay buffer (50 mM Tris, $5 \mathrm{mM}$ EDTA, pH 7.4), 100 $\mu \mathrm{l}$ standards or unknowns, $\left[{ }^{3} \mathrm{H}\right]$-cAMP $(10,000$ cpm/tube), and cAMP binding protein sufficient to bind $40-60 \%$ of the radioactivity in a final volume of $250 \mu \mathrm{l}$. The tubes were incubated for $90 \mathrm{~min}$ on ice. Dextran-coated charcoal $(0.5$ $\mathrm{mg} / \mathrm{ml}$ dextran and $5.0 \mathrm{mg} / \mathrm{ml}$ charcoal) was added to each tube $(600 \mu \mathrm{l})$, incubated an additional $30 \mathrm{~min}$ on ice, then centrifuged to remove the unbound from the bound cAMP-binding protein- $\left[{ }^{3} \mathrm{H}\right]$-cAMP complexes. The supernatant was decanted directly into scintillation vials and counted in a liquid scintillation spectrophotometer. Samples were run in duplicate and the concentration of cAMP was calculated by the log-logit method using Securia 1.0 (Packard Instruments, Indianapolis, IN). Data were expressed as $\mathrm{pmol} \mathrm{cAMP} / \mu \mathrm{g}$ DNA or as a ratio of T/C (PTH-stimulated vs. vehicle control).

\section{Statistical Analysis}

Data for the adenylate cyclase assays were evaluated using Instat 1.1 (GraphPAD Software, Inc., San Diego, CA) and an MS/DOS computer. Analysis of variance followed by multiple comparisons using a Tukey's mean separation test were used to determine statistically significant $(P<0.05)$ differences between groups. Nonlinear regression of the binding curve for PTHrP was performed with Prism (iii) (Graph Pad Software, San Diego, CA) using nonlinear curve fitting. Autoradiographs from the northern blot analysis were evaluated for relative signal density with NIH Image Software on a MacIntosh computer.

\section{RESULTS}

MC3T3-E1 cells were plated and allowed to attach overnight. The next day fresh media containing ascorbic acid and $\beta$-glycerophosphate was added. The first few days was a period of rapid proliferation. The cells reached confluence by day 3-4 but continued to proliferate as reflected by a 12 -fold increase in cellular DNA through the culture period (Fig. 1). Since the primary calvarial osteoblasts were isolated directly from fetal calvaria subjected to collagenase digestion, a longer acclimation period was allowed prior to the addition of ascorbic acid and $\beta$-glycerophosphate ( $2-3$ day). The DNA levels at day 0 were 


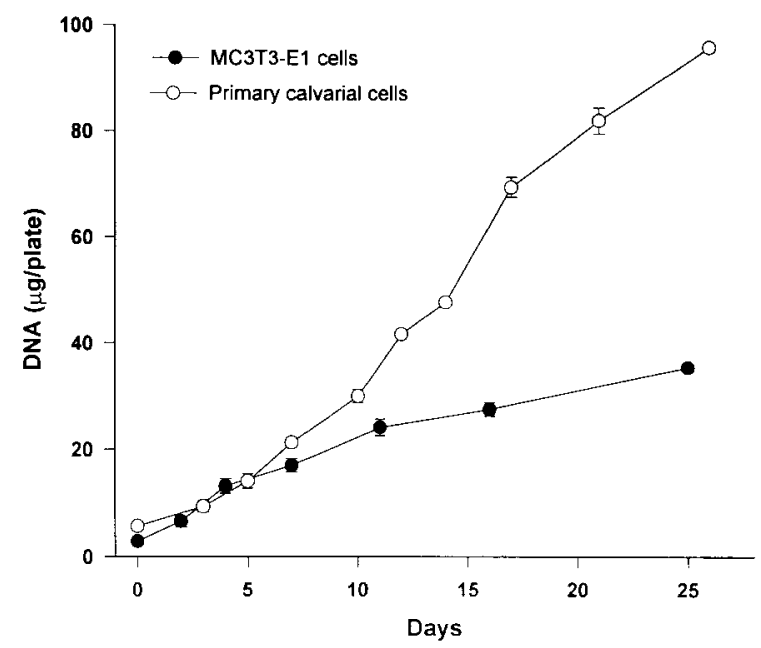

Fig. 1. Effects of differentiation on DNA levels in osteoblastic cells. Cells were plated at $10,000-20,000 / \mathrm{cm}^{2}$ and induced to differentiate with the addition of ascorbic acid $(50 \mu \mathrm{g} / \mathrm{ml})$. At the indicated time points, samples were collected and DNA values determined in triplicate by fluorometric analysis. The data are a representative plot from one of three experiments and are expressed as mean \pm standard deviation of triplicate determinations.

similar to the MC3T3-E1 cells, however, slightly higher and increased 17-fold over the 26 day culture period. Steady state mRNA levels for the $\mathrm{PTH} / \mathrm{PTHrP}$ receptor in MC3T3-E1 cells were initially low, and increased 4-fold to peak levels at day 4 (Fig. 2). Subsequently, mRNA levels for the PTH/PTHrP receptor gradually declined through the culture period. The primary calvarial cells followed a similar pattern with a 3-fold increase in PTH/PTHrP receptor steady state mRNA reaching a peak at day 5 , and declining thereafter.

To determine whether there was an alteration in the number of receptors or the binding affinity of $\mathrm{PTH} / \mathrm{PTHrP}$ receptors during differentiation, competition binding curves were performed at various time points during the culture period. Figure 3 contains binding curves for MC3T3-E1 cells during differentiation. There was specific binding of PTHrP to MC3T3-E1 cells at all time points during the culture period; however, initially the binding curve was relatively flat. Peak levels of cpm specifically bound to MC3T3-E1 cells occurred at day 7. Further increases in total binding were attributed to a concomitant increase in non-specific binding. The EC50 and number of receptors per $\mu \mathrm{g}$ DNA are listed in Table I, and account for the alterations in cell number during the culture period. For the early time periods the levels of binding
A

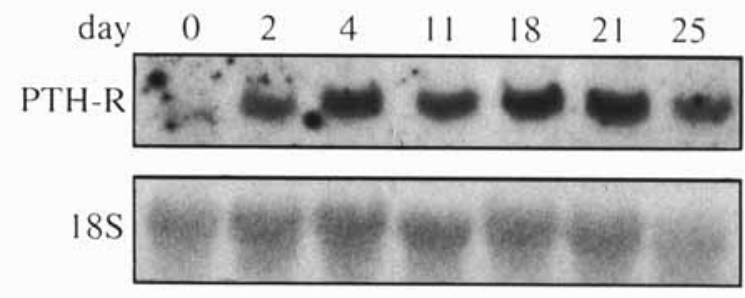

B
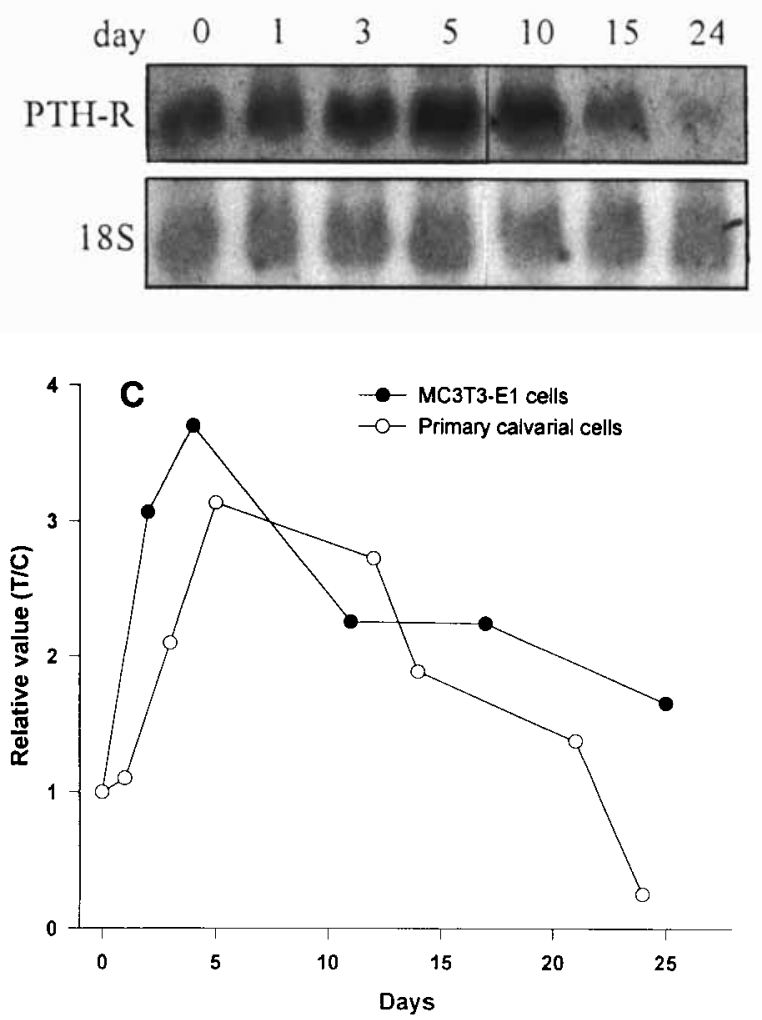

Fig. 2. PTH/PTHrP receptor $m R N A$ expression during differentiation. A: Autoradiograph of northern blot analysis of PTH/ PTHrP receptor mRNA and 18S rRNA isolated from MC3T3-E1 cells during differentiation. B: Autoradiograph of northern blot analysis of $\mathrm{PTH} / \mathrm{PTHrP}$ receptor mRNA and $18 \mathrm{~S}$ rRNA isolated from primary calvarial cells during differentiation. Autoradiographs are a representative sample from three experiments. C: Plot of mean values of relative expression (PTH/PTHrP receptor vs. 18S rRNA expressed relative to the expression at time zero) from two separate experiments.

were too low to obtain accurate EC50 and $\mathrm{B}_{\max }$ values. During the culture period the EC50 values were similar, with the highest affinity reached at day 14 ; however, the number of receptors per cell was highest at day 3 and was lower at day 14. Similar results were found for the primary calvarial cells. The binding affinity was highest at day 12; however, the numbers of 


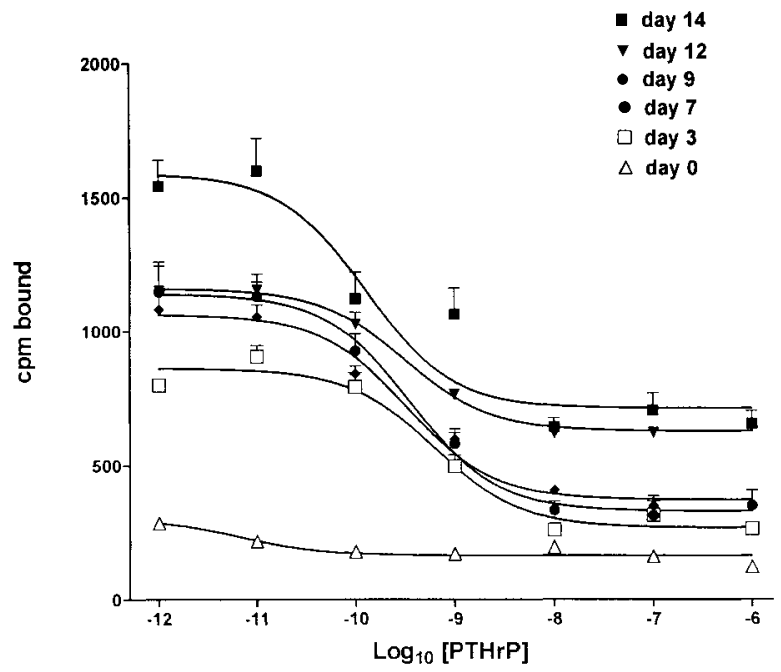

Fig. 3. Competition binding curves for MC3T3-E1 cells during differentiation. MC3T3-E1 cells were plated at $10,000 / \mathrm{cm}^{2}$ and induced to differentiate with the addition of ascorbic acid. Competition binding curves were performed using 20,000 cpm ${ }^{125}$ I-PTHrP (1-36) and the indicated concentrations of noniodinated PTHrP (1-34) from day 0-14. Data is expressed as mean \pm SEM for triplicate samples from one of three experiments with similar results. Derived values for EC50 and number of binding sites are in Table I.

TABLE I. Binding Analysis of MC3T3-E1 Cells*

\begin{tabular}{rcc}
\hline Day & EC50 & \# Receptors/ $\mu \mathrm{g}$ DNA \\
\hline 0 & - & - \\
3 & $6.35 \mathrm{e}-10$ & $9.72 \mathrm{e} 8$ \\
7 & $3.64 \mathrm{e}-10$ & $8.76 \mathrm{e} 8$ \\
9 & $3.34 \mathrm{e}-10$ & $8.64 \mathrm{e} 8$ \\
12 & $3.17 \mathrm{e}-10$ & $7.68 \mathrm{e} 8$ \\
14 & $1.29 \mathrm{e}-10$ & $3.14 \mathrm{e} 8$ \\
\hline
\end{tabular}

*Calculated using nonlinear regression and Scatchard analysis of data from competition binding curves depicted in Figure 3 .

receptors was greatest at day 5 (Fig. 4 and Table II).

In order to correlate biologic activity with the presence of the $\mathrm{PTH} / \mathrm{PTHrP}$ receptor, an evaluation of PTHrP-stimulated cAMP levels during differentiation was performed. The data reported in Figure 5, is expressed as a ratio of $\mathrm{T}$ (PTHrP stimulated samples) vs. C (non-stimulated) since there were slight increases in basal cAMP levels during the culture period. The mean basal cAMP levels ranged from 0.99 to 2.49 , and 0.46 to $5.65 \mathrm{pmol} / \mu \mathrm{g}$ DNA for the MC3T3-E1 and primary calvarial cells respectively. The PTHrP-stimulated cAMP values ranged from 85.29 to 212.30 , and 4.86 to $478.10 \mathrm{pmol} / \mu \mathrm{g}$

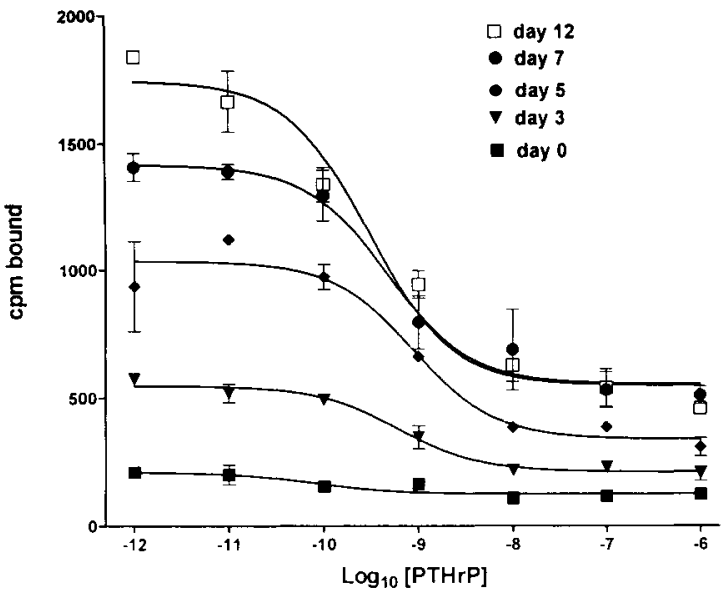

Fig. 4. Competition binding curves for primary calvarial cells during differentiation. Primary calvarial cells were isolated and plated at $20,000 / \mathrm{cm}^{2}$ and induced to differentiate with the addition of ascorbic acid. Competition binding curves were performed using 20,000 cpm ${ }^{125} \mathrm{I}$-PTHrP (1-36) and the indicated concentrations of non-iodinated PTHrP (1-34) from day $0-12$. Data is expressed as mean \pm SEM for triplicate samples from one of two experiments with similar results. Derived values for EC50 and number of binding sites are in Table II.

TABLE II. Binding Analysis of Primary Calvarial Cells*

\begin{tabular}{ccc}
\hline Day & EC50 & \# Receptors $/ \mu \mathrm{g}$ DNA \\
\hline 0 & - & - \\
3 & $6.18 \mathrm{e}-10$ & $1.32 \mathrm{e} 9$ \\
5 & $8.93 \mathrm{e}-10$ & $5.25 \mathrm{e} 9$ \\
7 & $4.72 \mathrm{e}-10$ & $1.83 \mathrm{e} 9$ \\
12 & $3.01 \mathrm{e}-10$ & $1.04 \mathrm{e} 9$ \\
\hline
\end{tabular}

*Calculated using nonlinear regression and Scatchard analysis of data from competition binding curves depicted in Figure 4.

DNA for the MC3T3-E1 and primary calvarial cells respectively. The $\mathrm{PTHrP}$-stimulated cAMP levels in MC3T3-E1 cells were initially low and increased 5 -fold to peak values at day 5 and decreased thereafter. The PTHrP-stimulated cAMP levels in the primary calvarial osteoblasts were also low initially and increased 6 -fold with a peak at day 4 and subsequently decreased to below initial values from day 17-26.

The studies reported in Figures 6-8 evaluated the requirements for ascorbic acid and collagen matrix synthesis in receptor expression. Experiments used the strategy and experimental conditions recently employed to demonstrate that ascorbic acid and collagen synthesis are necessary for the induction of alkaline phosphatase and osteocalcin in MC3T3-E1 cells [Franceschi 


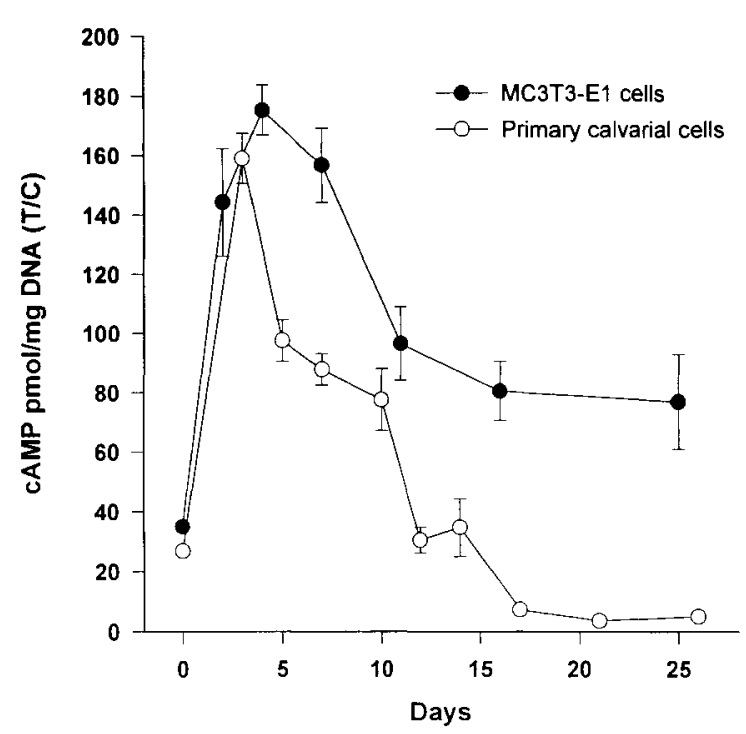

Fig. 5. Effects of differentiation on PTHrP-stimulated cAMP levels in osteoblastic cells. Cells were plated at 10,000-20,000/ $\mathrm{cm}^{2}$ and induced to differentiate with ascorbic acid $(50 \mu \mathrm{g} / \mathrm{ml})$. At the indicated time periods, samples were either stimulated with PTHrP (1-34) $(10 \mathrm{nM})$ or vehicle control for $10 \mathrm{~min}$. The CAMP levels are expressed as the ratio of PTHrP-stimulated/ control (mean \pm SEM for triplicate samples from one of two experiments with similar results).

and Iyer, 1992; Franceschi et al., 1994]. In the experiment in Figure 6, cells were grown for 3 days in control and ascorbic acid-containing medium before cAMP production in the presence and absence of PTH was measured. Ascorbic acid did not affect basal cAMP levels, but doubled PTH-dependent cAMP production. Figure 7 indicates that collagen synthesis is also required for the expression of the PTH/PTHrP receptor. Control and ascorbic acid-treated MC3T3-E1 cells were grown in the presence or absence of 3,4-dehydroproline (3,4-DHP), a specific inhibitor of triple-helical collagen formation. Ascorbic acid increased receptor mRNA 4-fold after 6 days and this stimulation persisted to day 8 and 10. In contrast, if 3,4-DHP was added with ascorbic acid at the start of the experiment, no stimulation of the PTH/PTHrP message was detected. However, if cells were pretreated with ascorbic acid for 6 days before inhibitor addition, no block in mRNA induction was seen after 2 or 4 additional days. Similar results were found for the effects of ascorbic acid and 3,4DHP on ${ }^{125} \mathrm{I}-\mathrm{PTHrP}$ binding to $\mathrm{PTH} / \mathrm{PTHrP}$ receptors in MC3T3-E1 cells (Fig. 8). Competition binding curves indicate that the EC50 values were not altered for the indicated treatment conditions. However, the numbers of receptors

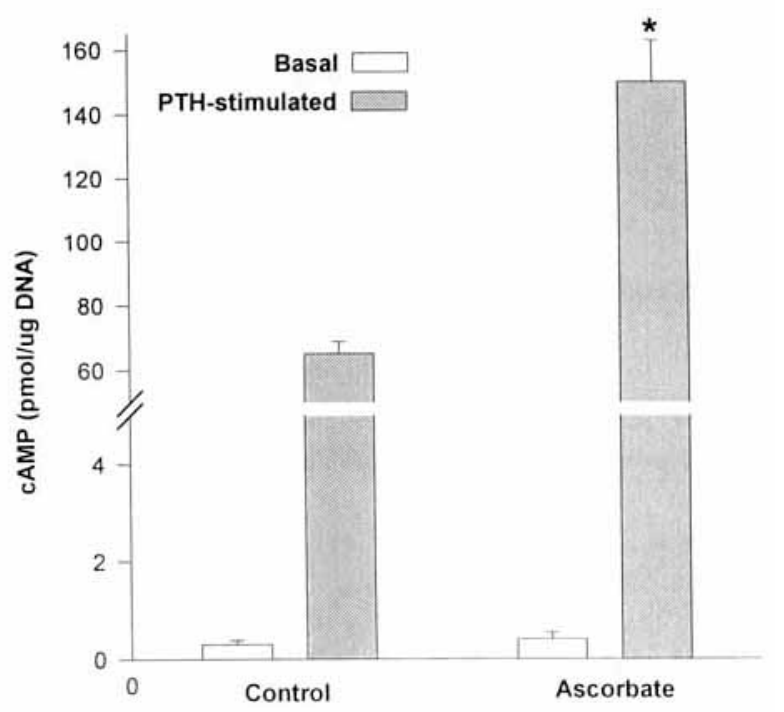

Fig. 6. Stimulation of PTH-dependent cAMP production by ascorbic acid. MC3T3-E1 cells were cultured in control or ascorbic acid-containing medium for 3 days followed by measurement of basal (open bars) or PTH (1-34)-stimulated (10 min) (hatched bars) cAMP levels. Values are expressed as mean \pm SEM for pmol cAMP normalized to ceil DNA.

were higher for the ascorbic acid-treated cells, and inhibition of collagen synthesis with 3,4DHP resulted in a reduction in receptor numbers to control values. Our previous work established that the concentration of 3,4-DHP used in this experiment $(500 \mu \mathrm{M})$ blocks greater than 95\% of total type I collagen synthesis [Franceschi et al., 1994]. Actions of this inhibitor are fully reversible and not associated with cellular toxicity. This was further substantiated since there was no significant difference in the DNA levels for the DHP treatment groups depicted in Figure 8 (data not shown).

\section{DISCUSSION}

The process of osteoblast differentiation has been characterized with a stepwise sequence of expression for phenotypic mineral-associated proteins [Lian and Stein, 1992]. Other studies have described the sequence of gene expression for osteocalcin, osteopontin, $\mathrm{H} 4$ histone, bone sialoprotein, c-fos, type I collagen, and alkaline phosphatase and related these phenotypic characteristics with matrix synthesis and the accumulation of calcium and phosphate in mineralized nodules [Kockx et al., 1994; Machwate et al., 1995; Ibaraki et al., 1992; Franceschi and Iyer, 1992]. Studies of this type provide valuable 
A
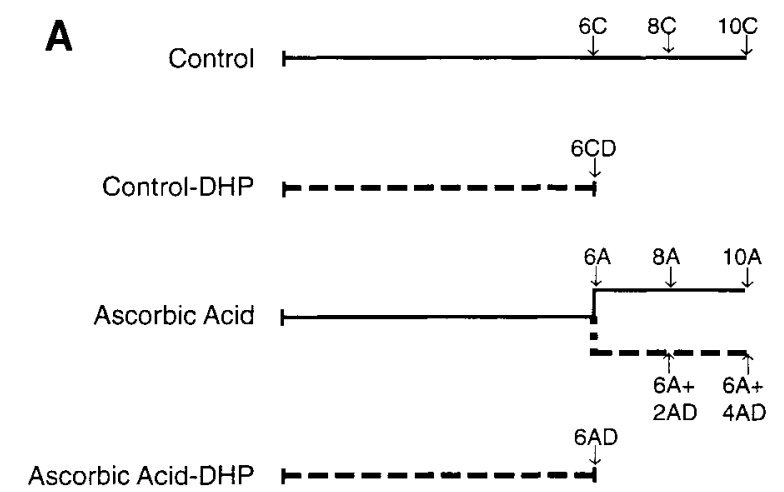

B

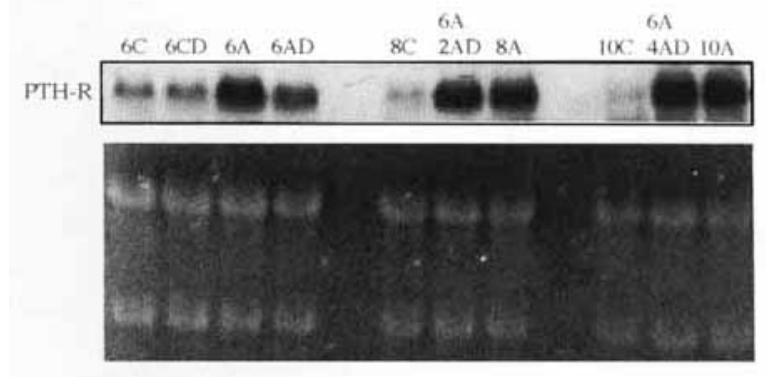

\section{C}

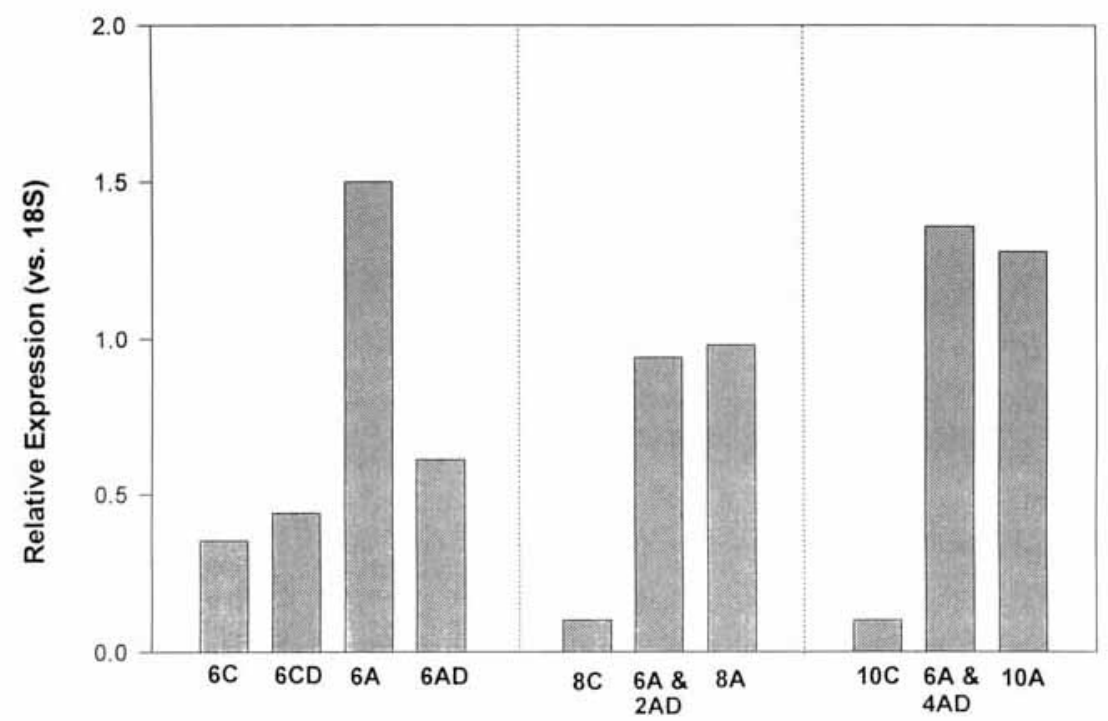

Fig. 7. Requirement of ascorbic acid and collagen matrix synthesis for expression of PTH/PTHrP receptor mRNA. A: Experimental outline: MC3T3-E1 cells were grown for 6 days in control medium $(6 \mathrm{C})$, control medium containing $500 \mu \mathrm{M}$ 3,4-DHP (6CD), medium containing $50 \mu \mathrm{g} / \mathrm{mL}$ ascorbic acid $(6 \mathrm{~A})$ or ascorbic acid-containing medium plus 3,4-DHP (6AD). Some control cultures were grown for an additional $2(8 \mathrm{C})$ or 4 (10C) days. At day 6 , ascorbic acid-treated cells were divided

information which has contributed to the understanding of osteoblast function. The present study determined the temporal pattern of gene expression, protein binding, and biologic activity for the PTH/PTHrP receptor in two calvarial osteoblastic cell systems. The MC3T3-E1 cells are a well-characterized immortalized osteoblastic cell line which undergo a specified pattern of differentiation in vitro [Franceschi and Iyer, 1992]. Primary rat calvarial cells were also utilized since these cells are used extensively in mineralized tissue research as a model of differentiation.

The results of the present study indicate that the PTH/PTHrP receptor is initially expressed in low to undetectable levels in both culture into the following groups: continued ascorbic acid treatment $(8 A, 70 A)$, ascorbic acid plus $3,4 \mathrm{DHP}$ for two $(6 A+2 A D)$ or four days $(6 A+4 A D)$. For each group, total RNA was isolated and northern blot hybridization performed. B: Representative autoradiograph of northern blot analysis for PTH/PTHrP receptor mRNA from two experiments, (C) Scanning densitometry of northern blot from (B) normalized to rRNA.

systems, and requires several days of differentiation induced by ascorbic acid for maximal expression. This is an important finding since many studies in the past have used the presence of a $\mathrm{PTH} / \mathrm{PTHrP}$ receptor as an indication that a cell is of the osteoblast lineage. The data presented in this investigation indicate that the time period of $\mathrm{PTH} / \mathrm{PTHr} \mathrm{P}$ receptor expression is dependent temporally on the differentiation state of the cell. Consequently, an immature osteoblastic cell or an inactive osteoblastic cell should not be discarded as being of the osteoblast lineage if it is not actively responding to PTH; however, a PTH-response may reflect the differentiation state of the osteoblast. 

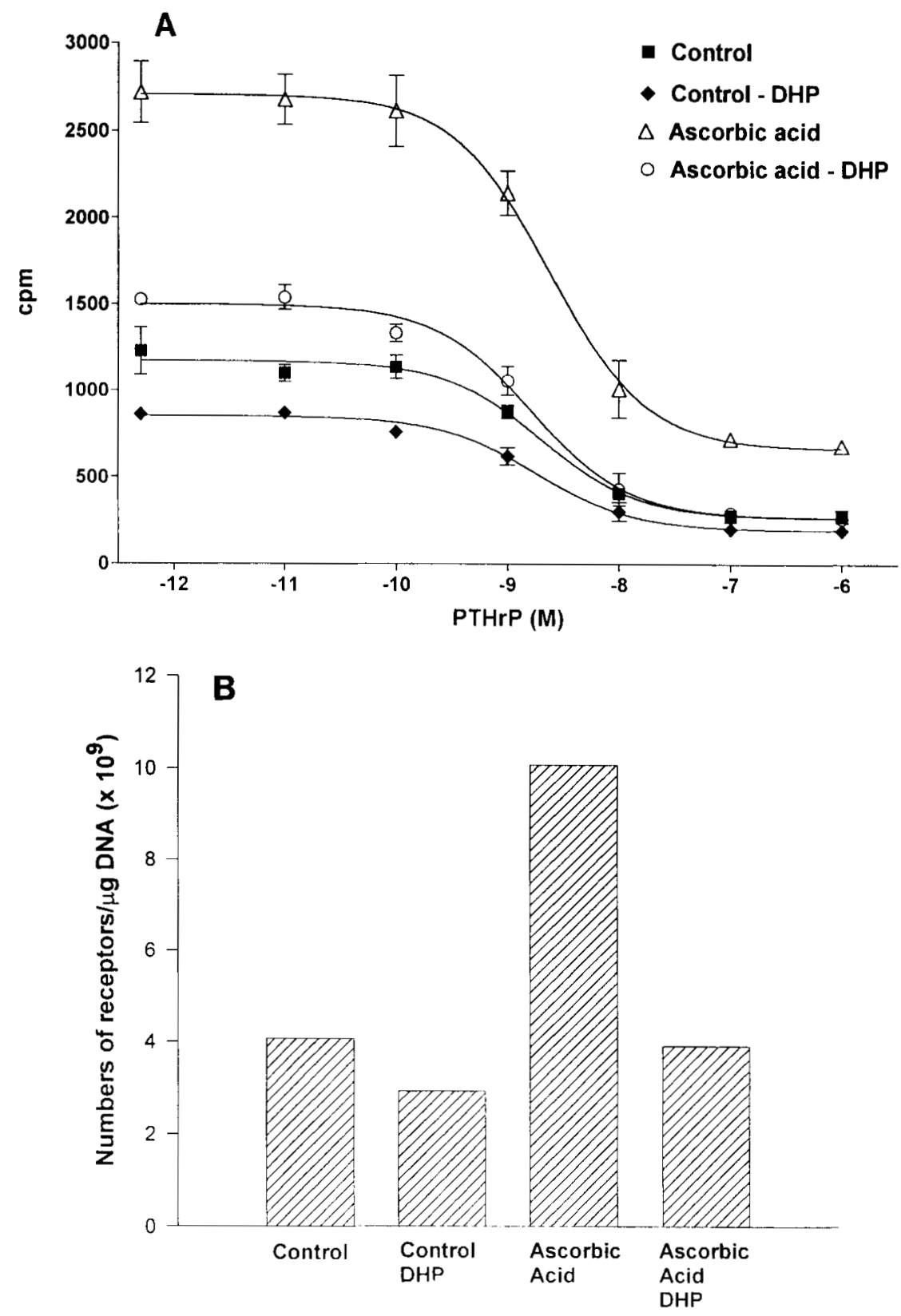

Fig. 8. Requirement of ascorbic acid and collagen matrix synthesis for PTH/PTHrP receptor binding. MC3T3-E1 cells were plated at $50,000 / \mathrm{cm}^{2}$ and cultured for 6 days in control medium, control medium containing $500 \mu \mathrm{M}$ 3,4-DHP, medium containing $50 \mu \mathrm{g} / \mathrm{mL}$ ascorbic acid, or ascorbic acidcontaining medium plus 3,4-DHP. A: Competition binding

These results are in agreement with in situ hybridization studies performed by Lee et al. [1994]. They reported the detection of mRNA signal for the PTH/PTHrP receptor over cuboidal cells lining the trabeculae in rat femur. These cells appeared to be active osteoblasts as determined by location and morphology. Low or unde- curves were performed using $20,000 \mathrm{cpm}{ }^{125} \mid$-PTHrP $(1-36)$ and the indicated concentrations of non-iodinated PTHrP (134). Data is expressed mean $\pm S E M$ for triplicate samples from one of two experiments with similar results. B: Scatchard analysis was utilized to determine the numbers of receptors per $\mu \mathrm{g}$ DNA for the experiment depicted in (A).

tectable signal was found over bone marrow stromal cells or osteocytes which may represent precursor and mature forms of cells of the osteoblast lineage respectively. A previous study, however, did not find the highest levels of PTH receptors over osteoblastic cells. Rouleau et al. performed an in vivo autoradiography study to 
identify cells which bound ${ }^{125}$ I-PTH-(1-34) [Rouleau et al., 1988]. They reported the presence of competitive binding to mature osteoblasts; however, the greatest binding was over large mononuclear cells in the intratrabecular space of the metaphyseal region of rat long bones. There was no definitive identification of this cell other than it had a large flattened cell body with numerous cytoplasmic extensions. Since the present study was performed with calvarial osteoblastic cells in vitro, cells of the lineage that Rouleau described were likely not present.

A study by Heath et al. [1989] described the isolation and immortalization of two rat calvarial cell lines, RCT-1 and RCT-3. The RCT-1 cells were described as immature and displayed a PTH-stimulated cAMP response only after 3 days of retinoic acid induced differentiation. The RCT-3 cells were described as active osteoblasts and constitutively displayed a PTH-stimulated cAMP. These findings support the concept that immature osteoblastic cells are dependent on differentiation for the expression and function of the PTH/PTHrP receptor.

In the present study, the highest numbers of receptors correlated with the maximal cAMP response. The small apparent variation in EC50 values for ligand binding (2-3-fold) are probably not significant. Instead, cAMP levels correlated with receptor number and not binding affinity.

The peak values of PTH/PTHrP receptor binding and biologic activity also coincided with the time period in which active matrix synthesis is initiated. This indicates that the synthesis of matrix surrounding the osteoblasts may regulate expression and activity of the PTH/PTHrP receptor as has been reported for other osteoblast markers [Franceschi and Iyer, 1992; Franceschi et al., 1994]. Consistent with this possibility, ascorbic acid strongly stimulated PTH/ PTHrP receptor mRNA levels and PTHdependent cAMP production. Furthermore, the ascorbic acid-dependent induction of receptor mRNA and ${ }^{125}$ I-PTHrP binding activity was completely blocked by a specific inhibitor of collagen matrix synthesis, 3,4-dehydroproline. This proline analog is incorporated into type I procollagen where it inhibits hydroxylation, triple helix formation, and subsequent extracellular matrix deposition [Vitto and Prockop, 1975]. If inhibitor addition was delayed until cells had already begun to form a collagenous matrix (day 6), further suppression of matrix production no longer interfered with receptor mRNA expres- sion. This result is similar to our previous findings with alkaline phosphatase and osteocalcin and suggests that short periods of collagen matrix synthesis generate a stable inductive signal for osteoblast marker gene expression. This signal may be generated by interactions between the extracellular matrix and cell surface receptors such as integrins or other components present in the matrix of ascorbic acid-treated cells.

In summary, the data presented here indicate that the $\mathrm{PTH} / \mathrm{PTHrP}$ receptor is associated temporally at the level of mRNA, protein and biologic activity with a differentiating, matrixproducing osteoblastic cell in vitro.

\section{ACKNOWLEDGMENTS}

We gratefully acknowledge Drs. Gino Segre, Harald Jüppner, and Abdul Abou-Samra for providing the $\mathrm{PTH} / \mathrm{PTHrP}$ receptor $\mathrm{CDNA}$ (R15B), and Dr. Richard Neubig for discussions on the analysis of the binding curves. These studies were supported by National Institutes of Health grants DK46919 (to L.K.M.), and DK35317 and DE11723 (to RTF) and the Michigan Arthritis and Musculoskeletal Diseases Center (P60 AR20557).

\section{REFERENCES}

Abou-Samra AB, Jüppner H, Force T, Freeman MW, Kong XF, Schipani E, Urena P, Richards J, Bonventre JV, Potts JT, Kronenberg HM, Segre GV (1992): Expression cloning of a common receptor for parathyroid hormone and parathyroid hormone-related peptide from rat osteoblast-like cells: A single receptor stimulates intracellular accumulation of both cAMP and inositol trisphosphates and increases intracellular free calcium. Proc Natl Acad Sci U S A 89:2732-2736.

Chomezynski P, Sacchi N (1987): Single-step method of RNA isolation by acid guanidinium thiocyanate-phenolchloroform extraction. Anal Biochem 162:156-159.

Franceschi RT, Iyer BS, Cui Y (1994): Effects of ascorbic acid on collagen matrix formation and osteoblast differentiation in murine MC3T3-E1 cells. J Bone Miner Res 9:843-854.

Franceschi RT, Wilson JT, Dixon SJ (1995): Requirement for $\mathrm{Na}(+)$-dependent ascorbic acid transport in osteoblast function. Am J Physiol 268 (6 Pt 1):C1430-C1439.

Franceschi RT, Iyer BS (1992): Relationship between collagen synthesis and expression of the osteoblast phenotype in MC3T3-E1 cells. J Bone Miner Res 7:235-246.

Heath JK, Rodan SB, Yoon K, Rodan GA (1989): Rat calvarial cell lines immortalized with SV-40 large T antigen constitutive and retinoic acid-inducible expression of osteoblastic features. Endocrinology 124:3060-3068.

Ibaraki K, Termine JD, Whitson SW, Young MF (1992): Bone matrix mRNA expression in differentiating fetal bovine osteoblasts. J Bone Miner Res 7:743-754.

Jüppner H, Abou-Samra A, Uneno S, Gu W, Potts JT, Segre GV (1988): The parathyroid hormone-like peptide associ- 
ated with humoral hypercalcemia of malignancy and parathyroid hormone bind to the same receptor on the plasma membrane of ROS 17/2.8 cells. J Biol Chem 263:88578560 .

Jüppner H, Abou-Samra AB, Freeman M, Kong XF, Schipani E, Richards J, Kolakowski LF, Hock J, Potts JT, Kronenberg HM, Segre GV (1991): A G protein-linked receptor for parathyroid hormone and parathyroid hormonerelated peptide. Science 254:1024-1026.

Kockx M, McCabe L, Stein JL, Lian JB, Stein GS (1994): Influence of DNA replication inhibition on expression of cell growth and tissue-specific genes in osteoblasts and osteosarcoma cells. J Cell Biochem 54:47-55.

Lee K, Deeds JD, Chiba S, Un-No M, Bond AT, Segre GV (1994): Parathyroid hormone induces sequential c-fos expression in bone cells in vivo: In situ localization of its receptor and c-fos messenger ribonucleic acids. Endocrinology 134:441-450.

Lian JB, Stein GS (1992): Concepts of osteoblast growth and differentiation: Basis for modulation of bone cell development and tissue formation. Crit Rev Oral Bio Med 3:269305.

Machwate M, Jullienne A, Moukhtar M, Marie PJ (1995): Temporal variation of c-fos proto-oncogene expression during osteoblast differentiation and osteogenesis in developing rat bone. J Cell Biochem 57:62-70.

Malaval L, Modrowski D, Gupta AK, Aubin JE (1994): Cellular expression of bone-related proteins during in vitro osteogenesis in rat bone marrow stromal cell cultures. J Cell Physiol 158:555-572.

McCauley LK, Rosol TJ, Capen CC (1992a): Effects of cyclosporin A on rat osteoblasts (ROS 17/2.8) in vitro. Calcif Tissue Int 51:291-297.

McCauley LK, Rosol TJ, Merryman JI, Capen CC (1992b): Parathyroid hormone-related protein binding to human T-cell lymphotropic virus type-I-infected lymphocytes. Endocrinology 130:300-306.

McCauley LK, Beecher CA, Melton ME, Werkmeister JR, Jüppner H, Abou-Samra AB, Segre GV, Rosol TJ (1994):
Transforming growth factor $\beta$ regulates steady state $\mathrm{PTH} /$ PTHrP receptor mRNA levels and PTHrP binding in ROS 17/2.8 osteosarcoma cells. Mol Cell Endocrinol 101:331336.

McCauley LK, Koh AJ, Beecher CA, Cui Y, Decker JD, Franceschi RT (1995): Effects of differentiation and transforming growth factor beta on PTH/PTHrP receptor mRNA levels in MC3T3-E1 cells. J Bone Miner Res 10: 1243-1255.

Pockwinse SM, Wilming LG, Conlon DM, Stein GS, Lian JB (1992): Expression of cell growth and bone specific genes at single cell resolution during development of bone tissuelike organization in primary osteoblast cultures. J Cell Biochem 49:310-323.

Renkawitz R, Gerbi SA (1979): Ribosomal DNA of the fly Sciara coprophila has a very small and homogenous repeat unit. Mol Gen Genet 173:1-13.

Rouleau MF, Mitchell J, Goltzman D (1988): In vivo distribution of parathyroid hormone receptors in bone: Evidence that a predominant osseous target cell is not the mature osteoblast. Endocrinology 123:187-191.

Tenenbaum HC, Heersche JNM (1982): Differentiation of osteoblasts and formation of mineralized bone in vitro. Calcif Tissue Int 34:76-79.

Turksen K, Aubin JE (1991): Positive and negative immunoselection for enrichment of two classes of osteoprogenitor cells. J Cell Biol 114:373-384.

Vitto J, Prockop DJ (1975): Inhibition of collagen accumulation with proline analogues: their mechanism of action. In Poppen H, Becker K (eds): "Collagen Metabolism in the Liver." New York: Stratton.

Wong G (1990): Isolation and behavior of isolated bone forming cells. In Hall BK (ed): "The Osteoblast and Osteocyte." Caldwell, New Jersey: The Telford Press.

Yamamoto I, Shigeno C, Potts JT, Segre GV (1988): Characterization and agonist-induced down-regulation of parathyroid hormone receptors in clonal rat osteosarcoma cells. Endocrinology 122:1208-1217. 